\title{
PENGUJIAN REAKSI INVESTOR TERHADAP PENGUMUMAN KABINET INDONESIA MAJU
}

\author{
Rexza Bramesta \\ PT. Dragon Product Indonesia \\ rexzabramesta@gmail.com
}

\begin{abstract}
Capital markets are relevantly influenced by political event. This research aimed to analyze the market reaction on the announcement of cabinet of Indonesia Maju on October, 23 2019. Market reaction is measured by abnormal return and trading volume activity. This study used 44 companies from LQ45 group's stock prices as population and used event study method to identify market reaction. The window event is 11 day long $(t-5-t+5)$. The statistical test used to test the hypotheses is simple t-test and paired sample test. The result of the statistical calculation of simple t-test showed there are no significant abnormal return around the date of the event. It means that investors do not respond to the event of newly cabinet announcement. The result of paired sample $t$-test showed there are no significant difference between the average abnormal return and trading volume activity obtained by sample companies listed in LQ45 index before and after the announcement of cabinet of Indonesia Maju.
\end{abstract}

Keywords: Market Reaction, Study of Events, LQ45

\section{PENDAHULUAN}

Iklim ekonomi di suatu negara selalu bersinggungan dengan pengaruh sosial dan politik yang terjadi di negara tersebut. Stabilitas politik menjadi salah satu faktor yang dipertimbangkan investor saat mempertimbangkan keputusan investasi. Hatmanti dan Sudibyo (2017) menemukan bahwa peristiwa politik dapat memberikan informasi baik bagi investor. Apabila kondisi politik negara tersebut rumit dan tidak suportif, akan timbul suatu ketidakpastian yang berdampak menurunnya atensi investor untuk masuk ke suatu negara. Salah satu "jalan masuk" investor ke suatu negara adalah melalui pasar modal. Di Indonesia, pasar modal Indonesia dikenal dengan nama Bursa Efek Indonesia (BEI). Menurut Undangundang no 8 tahun 1995 tentang Pasar Modal, pasar modal mempunyai peran strategis dalam pembangunan nasional sebagai salah satu sumber pembiayaan bagi dunia usah dan wahana investasi 
bagi masyarakat. BEI sebagai pasar modal memiliki peran makro bagi pembangunan nasional di Indonesia. Oleh sebab itu, situasi internal dan eksternal di Indonesia secara langsung dan tidak langsung dapat mempengaruhi elemen-elemen pasar modal di Indonesia. Tahun 2019 merupakan tahun politik bagi Indonesia karena tahun ini Pemilihan Umum Presiden dan Wakil Presiden dilaksanakan. Peristiwa ini merupakan peristiwa signifikan karena pergantian presiden dapat menimbulkan potensi perubahan kebijakan baru di bidang ekonomi. Selain itu, efek pemilu pilpres dapat mengakibatkan kondisi keamanan di Indonesia terganggu karena iklim politik yang bersifat adu domba. Dengan pertimbangan tersebut investor pasar modal perlu mempertimbangkan kejadian pemilu dalam pengambilan keputusan investasi. Walaupun demikian, beberapa penelitian empiris secara sederhana menyimpulkan bahwa peristiwa terkait pemilu tidak memiliki efek yang signifikan terhadap indeks harga saham. Melati (2016) dan Sudewa \& Sari (2015) menemukan tidak ada perbedaan abnormal return saham pada saat sebelum dan sesudah peristiwa pemilihan presiden pada tahun 2014.
Kondisi yang sama juga ditemukan pada saat Pemilihan Presiden Amerika Serikat pada tahun 2016. Sari (2017) menemukan bahwa hanya volume perdagangan saham yang memiliki perbedaan signifikan sebelum dan sesudah dilaksanakannya pemilihan presiden Amerika Serikat yang dimenangkan oleh Donald Trump. Reaksi pasar yang diproksikan dengan abnormal return pada event ini terbukti tidak signifikan. Hasil temuan penelitian-penelitian ini menunjukkan investor tidak bereaksi pada peristiwaperistiwa utama. Hal ini mungkin dapat disebabkan investor secara agregat telah bereaksi pada peristiwa-peristiwa yang lebih minor tetapi secara langsung terkait dengan peristiwa utamanya. Sehingga efek peristiwa tidak tertangkap secara agregat melalui satu peristiwa utama melainkan tercermin pada beberapa peristiwa yang lebih kecil. Penelitian ini dilaksanakan dengan mempertimbangkan faktor tersebut. Peristiwa pemilihan presiden merupakan peristiwa utama yang bagi banyak masyarakat merupakan peristiwa final dalam siklus peristiwa politik. Namun, setelah pemilihan presiden terdapat beberapa post peristiwa yang juga penting. Salah 
satunya adalah pengumuman kabinet presiden. Peristiwa pengumuman kabinet merupakan peristiwa yang memiliki konten informasi dikarenakan peristiwa ini memiliki efek langsung terhadap pasar modal. Contohnya kementerian BUMN yang memiliki perusahaan-perusahaan "plat merah" yang terdaftar di Bursa Efek Indonesia. Bahkan perusahaan dengan kapitalisasi pasar tertinggi dipegang oleh BUMN (Bank Rakyat Indonesia). Pengumuman kabinet berpotensi dapat mengubah pandangan investor terhadap pasar modal secara keseluruhan. Dengan demikian, peristiwa ini layak untuk dijadikan peristiwa pengujian reaksi pasar. Pengumuman kabinet Indonesia Maju dilangsungkan pada tanggal 23 Oktober 2019 pukul 10.00 WIB. Pada pengumuman tersebut, presiden terpilih, Joko Widodo, membuat suatu kejutan dengan menunjuk beberapa nama baru sebagai menteri yang berasal dari kalangan muda dan nonpolitik. Peristiwa pengumuman kabinet memenuhi peristiwa untuk dilakukan event study. Pengujian event study pada awalnya lebih terfokus pada peristiwaperistiwa internal perusahaan, seperti laporan tahunan, pengumuman deviden, stock split, dan sebagainya. Sekarang aplikasi terhadap metode event study telah mengalami suatu perkembangan, dimana pengujiannya tidak terbatas pada corporate event saja, namun telah melebar ke aspek makro ekonomi bahkan politik hingga keuangan (Arde \& Kesuma, 2017). Pengujian kandungan informasi atau event study bertujuan untuk melihat reaksi pasar secara agregat dari suatu peristiwa. Jika pengumuman suatu peristiwa mengandung informasi, pasar akan bereaksi secara positif atau negatif pada saat menerima informasi tersebut. Kecepatan reaksi antara pengumuman dan pengaruhnya terhadap harga saham menunjukkan kekuatan efisiensi bursa (Alrhafynza \& Siswanto, 2018). Semakin efisien suatu pasar, maka semakin cepat reaksi pasar dalam menyesuaikan harga baru. Reaksi pasar sering diukur menggunakan abnormal return (Melati, 2016; Ateris Bilada, 2010; Maharani, 2018). Abnormal return diukur dari selisih antara return realisasian dengan return ekspektasian (Jogiyanto, 2014). Selain itu, penelitian ini juga menggunakan variabel volume perdagangan saham untuk menjadi variabel konfirmatif dalam menjelaskan reaksi pasar secara agregat yang terjadi pasca pengumuman kabinet RI. 
Wardhani (2013) mengungkapkan bahwa peningkatan volume di pasar modal merupakan salah satu bentuk reaksi pasar modal terhadap suatu pengumuman peristiwa. Selanjutnya

\section{TELAAH LITERATUR}

Efisiensi Pasar

Teori pasar efisien dicetuskan pertama kali oleh Fama (1970). Konsep dasar pasar efisien ialah pasar dikatakan efisien apabila tidak ada satu orangpun yang dapat memperoleh return tidak normal (abnormal return) pada kondisi informasi yang sama. Dengan definisi tersebut, harga-harga saham yang terbentuk dipasar merupakan refleksi langsung seluruh informasi yang ada. Harga saham akan secara cepat menyesuaikan harga baru bila terdapat informasi baru. Semakin cepat informasi tersebut direfleksikan pada harga saham, maka semakin efisien pasar tersebut. Investor tidak akan mendapatkan return abnormal secara signifikan apabila pasar dikategorikan sebagai pasar efisien. Terdapat tiga jenis kategori pasar efisien yang dibentuk Fama (1970), yaitu (1) informasi harga saham masa lalu (information in past stock prices), (2) semua informasi publik (all public information), dan (3) penelitian ini akan dijelaskan dalam beberapa bagian yaitu bagian (ii) telaah literatur, bagian (iii) metodologi penelitian, bagian (iv) hasil dan analisis, dan bagian terakhir yaitu kesimpulan.

semua informasi yang ada termasuk informasi orang dalam (all available information including inside or private information). Kelompok-kelompok ini menentukan sejauh mana efisiensi suatu pasar di suatu negara. Gumanti dan Utami (2002) menyebutkan bahwa informasi dapat diklasifikasikan menjadi dua informasi, yaitu informasi yang telah diketahui dan informasi yang bersifat dugaan. Informasi yang sudah diketahui meliputi dua macam, yaitu informasi masa lalu (misalnya laba tahun atau kuartal yang lalu) dan informasi saat ini (current information) selain juga kejadian atau peristiwa yang telah diumumkan tetapi masih akan terjadi (misalnya rencana pemisahan saham). Contoh untuk informasi yang masih membutuhkan dugaan adalah jika banyak investor percaya bahwa suku bunga akan segera turun, harga-harga akan mencerminkan kepercayaan ini sebelum penurunan sebenarnya terjadi. Hipotesis Pasar Efisien 
Menurut Fama (1970) dalam Hartono (2016) mengatakan bahwa di mana terdapat tiga hipotesis pasar efisien berdasarkan informasi yang digunakan, yaitu:

1. Pasar efisien bentuk lemah (weak form)

Pasar dikatakan efisien dalam bentuk lemah jika harga-harga dari sekuritas tercermin secara penuh (fully reflect) informasi masa lalu. Informasi masa lalu merupakan informasi yang sudah terjadi. Bentuk efisiensi pasar secara lemah ini berkaitan dengan teori langkah acak (random walk theory) yang menyatakan bahwa data masa lalu tidak berkaitan dengan nilai sekarang. Efisiensi pasar bentuk lemah menyatakan bahwa investor tidak dapat menggunakan informasi masa lalu untuk mendapatkan keuntungan yang tidak normal (abnormal return).

2. Pasar efisien bentuk setengah kuat (semi-strong form)
Pasar dikatakan efisien setengah kuat jika harga-harga sekuritas secara penuh mencerminkan (fully reflect) semua informasi yang dipublikasikan (all publicly available information) termasuk informasi yang berada di laporan-laporan keuangan perusahaan emiten. Pada pasar efisien bentuk setengah kuat, return tak normal hanya terjadi di seputar pengumuman (publikasi) suatu peristiwa dengan implikasi tidak ada investor/grup investor yang dapat menggunakan informasi yang dipublikasikan untuk menerima keuntungan tidak normal/abnormal return dalam jangka waktu yang lama.

3. Pasar efisien bentuk kuat (strong form)

Pasar dikatakan efisien dalam bentuk kuat jika harga-harga sekuritas secara penuh mencerminkan semua informasi yang tersedia termasuk informasi yang privat. Jika pasar efisien dalam bentuk ini, tidak ada individual investor/grup 
investor yang dapat memperoleh keuntungan tidak normal karena mempunyai informasi private.

\section{Return Saham}

Return saham merupakan imbal hasil yang diperoleh investor dari investasi dan perdagangan saham. return didapatkan dari selisih harga jual dengan harga beli dari saham yang diperdagangkan. Terdapat dua jenis return dalam transaksi perdagangan saham yaitu return normal dan return tak normal (Hartono, 2015). return normal adalah return ekspektasian atau return yang diharapkan oleh investor. Sementara return taknormal merupakan kelebihan dari return yang sesungguhnya terjadi terhadap return taknormal. Pengujian peristiwa menggunakan return tak normal sebagai variabel yang ditelaah. return tak normal menunjukkan angka return yang berhasil didapatkan investor akibat

\section{METODOLOGI PENELITIAN}

Penelitian ini menggunakan adalah studi peristiwa. Studi peristiwa adalah studi yang melibatkan analisis perilaku harga saham sekitar waktu kejadian atau pengumuman informasi (Hartono, 2015). Tujuan penelitian ini untuk terjadinya suatu peristiwa atau pengumuman. return kejutan ini dapat mengindikasikan berita baik ataupun berita negatif dari suatu peristiwa. Selain klasifikasi return normal dan tak normal. Jenis return dapat diklasifikasikan menjadi return realisasi dan return ekspektasian. return realisasi merupakan return yang telah terjadi, dan perhitungannya menggunakan data histori perusahaan yang berguna untuk mengukur kinerja perusahaan. return realisasi atau disebut juga return historis berguna juga untuk menentukan return ekspektasi (expected return) dan risiko di masa yang akan datang. return ekspektasian adalah nilai return yang diharapkan oleh investor. return ini digunakan untuk pengambilan keputusan investasi. return ini lebih penting dibandingkan return historis (realisasi) karena return ini yang diharapkan oleh semua investor di masa yang akan datang.

menganalisis dampak peristiwa pengumuman kabinet terhadap indeks saham LQ45 yang ada di Bursa Efek Indonesia. Peristiwa ini merupakan peristiwa politik yang berskala nasional dan memiliki hubungan erat dengan 
pasar modal Indonesia. Jenis data yang digunakan dalam penelitian ini adalah data kuantitatif yaitu harga dan jumlah saham yang diperdagangkan (volume) setiap emiten yang masuk kedalam populasi. Sumber data yang digunakan adalah data sekunder berupa data dan informasi yang telah diterbitkan oleh pihak lain. Data harga saham dan volume perdagangan diambil dari website idx.co.id. Populasi penelitian ini adalah saham yang terdaftar di indeks LQ45. Indeks LQ45 adalah indeks yang memuat saham-saham paling likuid dan memiliki kapitalisasi pasar besar yang anggotanya diperbaharui setiap enam bulan sekali. Indeks LQ45 mencakup saham-saham dari seluruh sektor industri yang ada di BEI antara lain: sektor pertanian, sektor pertambangan, sektor industri dasar dan kimia, sektor aneka industri, sektor industri barang konsumsi, sektor properti dan real estat, sektor transportasi dan infrastruktur, sektor keuangan, dan sektor perdagangan, jasa, dan investasi. Penelitian studi peristiwa memerlukan rancangan garis waktu yang terdiri dari periode estimasi dan periode jendela. Panjang periode estimasi dalam penelitian ini adalah 50 hari. Periode estimasi dalam penelitian ini dibuat tidak terlalu panjang sehingga mengurangi potensi kehilangan sampel akibat confounding effect. Sedangkan panjang periode jendela adalah 11 hari yaitu 5 hari sebelum pengumuman, 1 hari pengumuman, dan 5 hari pasca pengumuman. Panjang periode jendela ditentukan 11 hari karena efek dari pengumuman kabinet diperkirakan tidak memiliki efek respon yang terlalu panjang. Tanggal peristiwa yang dipilih adalah tanggal 23 Oktober 2019 bertepatan dengan pengumuman kabinet Indonesia Maju. Berikut merupakan gambaran pada periode penelitian ini sebagai berikut: 
Gambar 1. Periode Penelitian

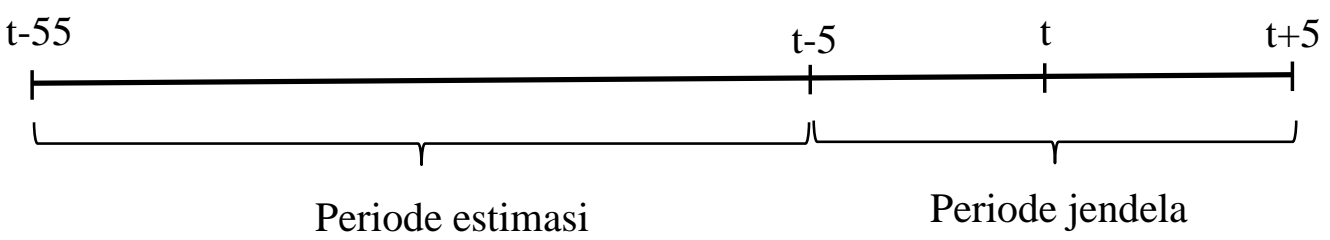

Teknik sampling yang digunakan dalam penelitian yang dilakukan oleh penulis adalah dengan menggunakan purposive sampling method. Pemilihan sampel berdasarkan kriteria yang dibutuhkan oleh peneliti sehingga ada aspek-aspek yang dikendalikan. Perusahaanperusahaan yang memiliki confounding effect seperti merger, akuisisi, stock split, pengumuman deviden dan lainnya pada periode estimasi dan jendela akan dikeluarkan dari sampel penelitian. Hal ini dikarenakan bahwa efek pengganggu akan menyebabkan pengukuran abnormal return terganggu baik dari pengukuran return realisasian maupun return ekspektasian. Menurut Sugiyono (2009) mengatakan bahwa variabel penelitian adalah suatu atribut seseorang, atau objek, yang mempunyai variasi antara satu orang dengan yang lain atau satu objek dengan objek yang lain dan ditetapkan oleh peneliti untuk dipelajari dan kemudian ditarik kesimpulannya. Variabel yang diukur dalam penelitian ini adalah abnormal return dan volume perdagangan saham, sehingga operasional yang akan penulis lakukan antara lain sebagai beriku 
Tabel 1. Operasionalisasi Variabel

\begin{tabular}{|c|c|c|c|}
\hline Variabel & Konsep & Pengukuran & Skala \\
\hline $\begin{array}{l}\text { Volume } \\
\text { Perdag. } \\
\text { Saham }\end{array}$ & $\begin{array}{l}\text { Proporsi saham yang } \\
\text { diperdagangankan dengan } \\
\text { jumlah saham yang } \\
\text { beredar pada titik waktu } \\
\text { tertentu }\end{array}$ & $T V A=\frac{\sum \text { saham i ditransaksikan wakt }}{\sum \text { saham i beredar waktu t }}$ & Rasio \\
\hline $\begin{array}{l}\text { Abnorm } \\
\text { al } \\
\text { return }\end{array}$ & $\begin{array}{l}\text { Selisih dari return yang } \\
\text { sesungguhnya } \\
\text { terhadap normal return } \\
\text { yang merupakan return } \\
\text { yang diharapkan oleh } \\
\text { investor (expected return). }\end{array}$ & $\begin{array}{c}\text { Market Adjusted Model } \\
\mathrm{ARi}_{\mathrm{t}}=\mathrm{Ri}_{\mathrm{t}}-\mathrm{ER} \\
\text { Dimana : } \\
\mathrm{Ri}_{\mathrm{t}}=\frac{\mathrm{Pi}_{\mathrm{t}}-\mathrm{Pi}_{\mathrm{t}-1}}{\mathrm{Pi}_{\mathrm{t}-1}} \\
E R_{i t}=R M_{i t} \\
\mathrm{RM}_{\mathrm{it}}=\frac{\mathrm{LQ} 45_{\mathrm{t}}-\mathrm{LQ} 45_{\mathrm{t}-1}}{\mathrm{LQ} 45_{\mathrm{t}-1}}\end{array}$ & Rasio \\
\hline
\end{tabular}

\section{HASIL DAN PEMBAHASAN}

Setelah melakukan sampling terhadap populasi penelitian terdapat sampel dapat dikatakan di mana total nya sebanyak 44 perusahaan yang akan diuji secara statistik. Berikut adalah daftar perusahaan yang menjadi sampel penelitian:

Tabel 2. Sampel Penelitian

\begin{tabular}{llc} 
No & Kode & Nama Emiten \\
1 & ADHI & Adhi Karya (Persero) Tbk. \\
2 & ADRO & Adaro Energy Tbk \\
3 & AKRA & AKR Corporindo Tbk. \\
4 & ANTM & Aneka Tambang Tbk. \\
5 & ASII & Astra International Tbk. \\
\hline
\end{tabular}




\begin{tabular}{|c|c|c|}
\hline No & Kode & Nama Emiten \\
\hline 6 & ASRI & Alam Sutera Reality Tbk. \\
\hline 7 & $\mathrm{BBCA}$ & Bank Central Asia Tbk. \\
\hline 8 & $\mathrm{BBNI}$ & Bank Negara Indonesia (Persero) Tbk. \\
\hline 9 & BBRI & Bank Rakyat Indonesia (Persero) Tbk. \\
\hline 10 & BBTN & Bank Tabungan Indonesia (Persero) Tbk. \\
\hline 11 & BMRI & Bank Mandiri (Persero) Tbk. \\
\hline 12 & BSDE & Bumi Serpong Damai Tbk. \\
\hline 13 & CPIN & Charoen Pokphand Indonesia Tbk. \\
\hline 14 & ELSA & Elnusa Tbk. \\
\hline 15 & EXCL & XL Axiata Tbk. \\
\hline 16 & GGRM & Gudang Garam Tbk. \\
\hline 17 & HMSP & HM Sampoerna Tbk. \\
\hline 18 & ICBP & Indofood CBP Sukses Makmur Tbk. \\
\hline 19 & INCO & Vale Indonesia Tbk. \\
\hline 20 & INDF & Indofood Sukses Makmur Tbk. \\
\hline 21 & INDY & Indika Energy Tbk. \\
\hline 22 & INKP & Indah Kiat Pulp \& Paper \\
\hline 23 & INTP & Indocement Tunggal Prakasa Tbk. \\
\hline 24 & ITMG & Indo Tambangraya Megah Tbk \\
\hline 25 & JSMR & Jasa Marga (Persero) Tbk. \\
\hline 26 & KLBF & Kalbe Farma Tbk. \\
\hline 27 & LPKR & Lippo Karawaci Tbk. \\
\hline 28 & LPPF & Matahari Department Store Tbk. \\
\hline 29 & MEDC & Medco Energi Internasional Tbk \\
\hline 30 & $\mathrm{MNCN}$ & Media Nusantara Citra Tbk. \\
\hline 31 & PGAS & Perusahaan Gas Negara (Persero) Tbk. \\
\hline 32 & PTBA & Tambang Batubara Bukit Asam (Persero) \\
\hline & & Tbk. \\
\hline 33 & PTPP & PP (Persero) Tbk. \\
\hline 34 & SCMA & Surya Citra Media Tbk. \\
\hline
\end{tabular}




\begin{tabular}{llc}
\hline No & Kode & Nama Emiten \\
35 & SMGR & Semen Indonesia (Persero) Tbk. \\
36 & SRIL & Sri Rejeki Isman Tbk. \\
37 & SSMS & Sawit Sumbermas Sarana Tbk. \\
38 & TLKM & Telekomunikasi Indonesia (Persero) Tbk. \\
39 & TPIA & Chandra Asri Petrochemical Tbk. \\
40 & UNTR & United Tractors Tbk. \\
41 & UNVR & Unilever Indonesia Tbk. \\
42 & WIKA & Wijaya Karya (Persero) Tbk. \\
43 & WSBP & Waskita Beton Precast Tbk. \\
44 & WSKT & Waskita Karya (Persero) Tbk. \\
\hline
\end{tabular}

Terdapat satu perusahaan yang dikeluarkan dari sampel yaitu Sentul City Tbk (BKSL) dikarenakan melakukan aksi korporasi berupa penerbitan waran pada periode penelitian. return realiasasi merupakan return yang telah terjadi dan didapatkan oleh investor pada suatu titik waktu tertentu. return realisasian dalam penelitian ini dihitung selama 11 hari yang terdiri dari 5 hari sebelum peristiwa, 5 hari setelah peristiwa dan 1 hari pada saat terjadinya peristiwa. Secara keseluruhan, terdapat 494 nilai return realisasian. return positif menandakan bahwa harga saham hari tersebut lebih tinggi dibanding hari sebelumnya. return negatif menunjukkan bahwa harga saham hari tersebut lebih rendah dibanding hari sebelumnya. Terakhir, return nol menunjukkan bahwa harga saham hari tersebut sama dengan hari sebelumnya. Dari data return realisasian yang diperoleh, sebanyak $47 \%$ return berupa return positif sementara $42,1 \%$ return berupa return negatif dan sisanya tidak menghasilkan return. Secara sekilas dapat dilihat bahwa data return realisasian tidak mengarah pada suatu pola tertentu namun beredar baik secara positif maupun negatif. Data lebih lengkap disajikan pada tabel 3 dibawah ini. 
Tabel 3. Frekuensi Jenis Return Realisasian Sampel Penelitian

\begin{tabular}{cccc}
\hline $\mathbf{t}$ & \multicolumn{3}{c}{ Return Realisasian } \\
& Positif & Nol & Negatif \\
-5 & 17 & 6 & 22 \\
-4 & 22 & 8 & 15 \\
-3 & 23 & 2 & 20 \\
-2 & 19 & 4 & 22 \\
-1 & 24 & 3 & 18 \\
0 & 28 & 4 & 13 \\
1 & 35 & 3 & 7 \\
2 & 4 & 6 & 35 \\
3 & 17 & 6 & 22 \\
4 & 22 & 6 & 17 \\
5 & 21 & 7 & 17 \\
\hline Jumlah & $\mathbf{2 3 2}$ & $\mathbf{5 5}$ & $\mathbf{2 0 8}$ \\
Persentase & $\mathbf{4 7 , 0 \%}$ & $\mathbf{1 1 , 1 \%}$ & $\mathbf{4 2 , 1 \%}$ \\
\hline
\end{tabular}

Tabel 4 menunjukkan data rata-rata return realisasian pada periode jendela. Dari hasil tabulasi data hampir seluruh titik waktu menunjukkan nilai return positif. Terdapat 9 hari dengan rata-rata return positif dan 2 hari dengan ratarata return negatif. Hasil ini sejalan dengan rekapitulasi data sebelumnya yang menunjukkan return dengan nilai dan frekuensi positif.

Tabel 4 Rata-rata Return Realisasian pada Periode Peristiwa

\begin{tabular}{cc}
$\mathbf{t}$ & Rata-rata return Realisasian \\
-5 & $0,01 \%$ \\
-4 & $0,39 \%$ \\
-3 & $0,58 \%$ \\
-2 & $0,17 \%$ \\
-1 & $0,08 \%$ \\
0 & $0,80 \%$ \\
1 & $1,65 \%$ \\
2 & $-1,49 \%$ \\
3 & $-0,04 \%$ \\
4 & $0,29 \%$ \\
5 & $0,02 \%$ \\
\hline
\end{tabular}


Return ekspektasian dalam penelitian ini dihitung dengan menggunakan market model. Nilai return ekspektasian diatur secara konstan untuk seluruh perusahaan menggunakan basis indeks LQ45 sesuai hari pada periode penelitian. Untuk mendapatkan nilai abnormal return, return realisasian dikurangkan dengan return ekspektasian. Abnormal return dapat bernilai positif maupun negatif. Berdasarkan hasil perhitungan nilai rata-rata abnormal return pada periode peristiwa terlampir pada tabel 5 dibawah ini.

Tabel 5. Rata-rata Abnormal Return Selama Periode Peristiwa

\begin{tabular}{cc}
$\mathbf{t}$ & Average Abnormal Return \\
-5 & $-0,33 \%$ \\
-4 & $-0,21 \%$ \\
-3 & $-0,09 \%$ \\
-2 & $0,08 \%$ \\
-1 & $-0,64 \%$ \\
0 & $-0,08 \%$ \\
1 & $-0,36 \%$ \\
2 & $0,52 \%$ \\
3 & $-0,29 \%$ \\
4 & $-0,17 \%$ \\
5 & $-0,10 \%$ \\
\hline
\end{tabular}

Gambar 2. Pergerakan Average Abnormal Return

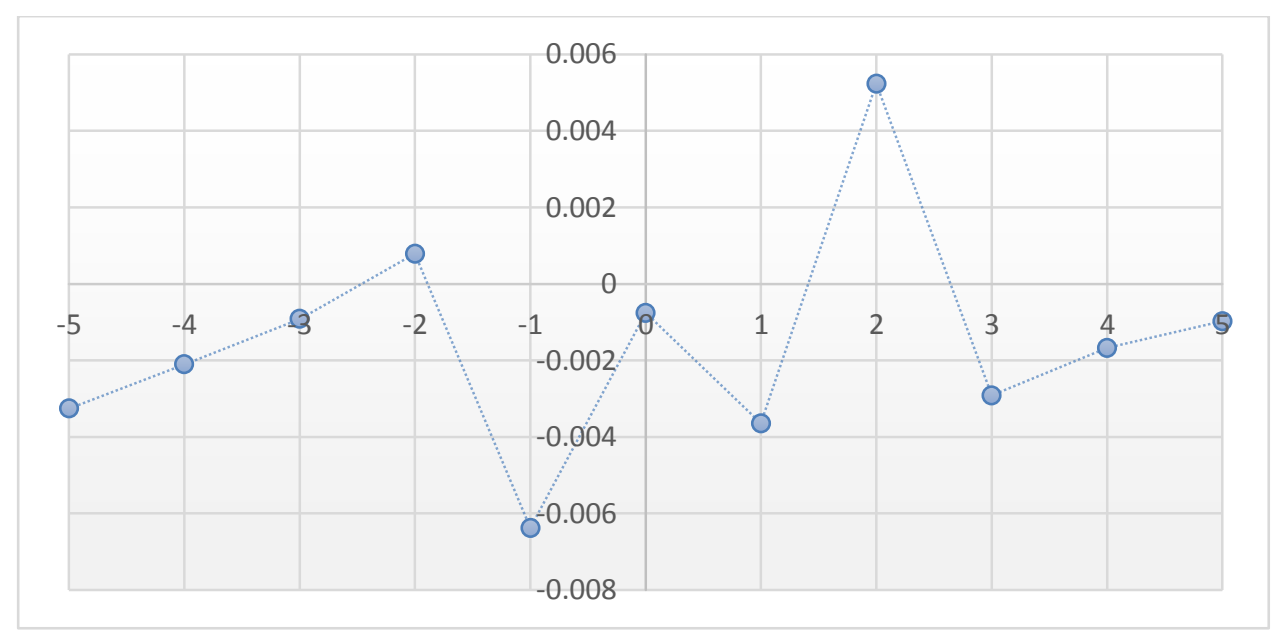


Nilai abnormal return menunjukkan bahwa investor mendapatkan return lebih dari apa yang seharusnya didapatkan. Berdasarkan tabel 5, terlihat bahwa rata-rata abnormal return pada 9 hari bernilai negatif sementara pada dua hari bernilai positif. Dapat dilihat abnormal return pada saat pengumuman bernilai hampir $0 \%$ Pasca pengumuman, return kemduian bernilai negatif, namun pada $\mathrm{t}+2$ abnormal return meningkat tajam hinggal lebih dari $300 \%$ dibanding hari sebelumnya. Hasil ini berkebalikan dengan saat rekapitulasi data return realisasian yang menghasilkan angka positif lebih banyak dibandingkan angka negatif. Namun hasil tabulasi diatas masih bersifat deskriptif tanpa kandungan signifikansi. Uji signifikansi diperlukan untuk memunculkan efek generalisasi pada populasi penelitian. Untuk menguji signifikansi pengujian hipotesis maka perlu dilakukan uji beda. Uji beda yang digunakan adalah uji t. Uji t digunakan untuk melihat reaksi pasar modal terhadap peristiwa pengumuman menteri kabinet Indonesia Maju pada 23 Oktober 2019. Uji t digunakan untuk menguji apakah terdapat abnormal return yang signifikan pada hari-hari sebelum dan sesudah peristiwa pengumuman tersebut. Berikut adalah hasil pengujian uji $t$ pada sampel penelitian.

Tabel 6. Hasil Uji-T Average Abnormal Return

\begin{tabular}{lrrrr} 
& \multicolumn{1}{c}{$\mathbf{t}$} & df & Sig. (2-tailed) & \multicolumn{1}{c}{$\begin{array}{c}\text { Mean } \\
\text { Difference }\end{array}$} \\
\cline { 1 - 3 } t-5 & $-1,687$ & 43 &, 099 &,- 00326 \\
$\mathrm{t}-4$ &,- 907 & 43 &, 369 &,- 00210 \\
$\mathrm{t}-3$ &,- 221 & 43 &, 826 &,- 00092 \\
$\mathrm{t}-2$ &, 271 & 43 &, 788 &, 00079 \\
$\mathrm{t}-1$ & $-2,700$ & 43 &, $010 *$ &,- 00638 \\
$\mathrm{t}$ &,- 245 & 43 &, 808 &,- 00076 \\
$\mathrm{t}+1$ & $-1,071$ & 43 &, 290 &,- 00364 \\
$\mathrm{t}+2$ & 1,761 & 43 &, 085 &, 00523 \\
$\mathrm{t}+3$ &,- 984 & 43 &, 331 &,- 00291 \\
$\mathrm{t}+4$ &,- 541 & 43 &, 591 &,- 00167 \\
$\mathrm{t}+5$ &,- 424 & 43 &, 674 &,- 00098 \\
\hline
\end{tabular}


Berdasarkan tabel 5, hasil uji $\mathrm{t}$ menunjukkan bahwa secara statistik, mayoritas hari pada periode penelitian menunjukkan nilai yang tidak signifikan. Hanya pada hari t-1 yaitu sehari sebelum pengumuman pasar mereaksi secara negatif. Dapat disimpulkan bahwa peristiwa pengumuman kabinet tidak memberikan return abnormal yang positif bagi investor. Pengujian statistik ini menunjukkan bahwa abnormal return tidak didapat oleh investor karena informasi pengumuman kabinet belum memiliki konten dengan relevansi tinggi bagi investor. Selain menghitung dan menguji rata-rata abnormal return, penelitian ini juga mempertimbangkan turunan abnormal return lainnya yaitu rata-rata abnormal return kumulatif (Cumulative Average Abnormal return). CAAR menghitung nilai kumulatif/akumulasi return suatu perusahaan pada rentang periode tertentu. Nilai CAAR mengindikasikan total return yang didapatkan oleh investor jika melakukan transaksi jual beli secara konsisten pada rentang waktu tersebut. Hasil pengujian uji $\mathrm{t}$ pada variabel CAAR dapat dilihat pada tabel 7 dibawah ini.

Tabel 7. Hasil Uji-T Cumulative Average Abnormal return

\begin{tabular}{|c|c|c|c|c|}
\hline & $\mathbf{t}$ & df & Sig. (2-tailed) & $\begin{array}{c}\text { Mean } \\
\text { Difference }\end{array}$ \\
\hline sebelum & $-1,700$ & 43 & ,096 &,- 01187 \\
\hline $\mathrm{t}$ &,- 245 & 43 & ,808 &,- 00076 \\
\hline sesudah &,- 801 & 43 & ,428 &,- 00398 \\
\hline
\end{tabular}

Berdasarkan hasil tabel 7, pengujian CAAR pada periode peristiwa secara statistik tidak signifikan untuk seluruh periode waktu baik sebelum, saat, maupun sesudah peristiwa pengumuman. Untuk sampel penelitian hasil penelitian menunjukkan bahwa nilai CAAR selalu negatif (dilihat dari tanda nilai t). Hasil ini sejalan karena pada pengujian deskriptif sebelumnya didominasi oleh return abnormal yang bernilai negatif. Jadi, hasil pengujian CAAR menunjukkan sekali lagi bahwa peristiwa pengumuman kabinet tidak memiliki konten informasi yang relevan bagi investor. Untuk konklusi akhir 
yang lebih kuat, maka dilakukan pengujian lanjutan untuk menguji apakah terdapat perbedaan rata-rata abnormal return sebelum dan sesudah peristiwa pengumuman. Pengujian menggunakan uji paired sample t-test.
Pengujian ini digunakan untuk menguji apakah terdapat perbedaan antara ratarata return yang terjadi sebelum dengan sesudah peristiwa pengumuman kabinet. Hasil pengujian disajikan pada tabel 8 dibawah ini.

Tabel 8. Hasil Uji Paired Sample Test

\begin{tabular}{rlrrrrr} 
& Mean & $\begin{array}{c}\text { Std. } \\
\text { Deviation }\end{array}$ & $\begin{array}{c}\text { Std. Error } \\
\text { Mean }\end{array}$ & \multicolumn{1}{c}{ t } & \multicolumn{2}{c}{$\begin{array}{c}\text { Sig. (2- } \\
\text { tailed) }\end{array}$} \\
Pair & sebelum & - &, 00449 &, 00201 &,- 785 &, 476 \\
& - &, 00158 & & & & \\
sesudah & & & & & \\
\hline
\end{tabular}

Dari hasil pengujian dapat dilihat bahwa nilai signifikansi yang dihasilkan adalah 0,476. Nilai ini lebih besar dari 0,05 yang menandakan bahwa hipotesis ditolak sehingga tidak ada perbedaan antara abnormal return sebelum peristiwa dengan abnormal return setelah peristiwa. Hasil ini menegaskan dua pengujian statistik sebelumnya yang menunjukkan bahwa peristiwa pengumuman kabinet Indonesia Maju tidak memiliki konten peristiwa yang dapat mempengaruhi reaksi pasar modal Indonesia khususnya untuk perusahaanperusahaan yang terdaftar di Indeks LQ45. Berdasarkan hasil yang diperoleh, dapat disimpulkan bahwa tidak terdapat perbedaan yang signifikan antara rata-rata abnormal return yang diperoleh perusahaan yang terdaftar di indeks LQ45 sebelum dan sesudah peristiwa pengumuman kabinet Indonesia Maju pada tanggal 23 Oktober 2019. Volume perdagangan saham diukur menggunakan persentase antara jumlah saham yang diperdagangkan dengan jumlah saham yang beredar pada waktu tersebut. Penelitian ini menggunakan variabel ini untuk melihat apakah ada transaksi yang melibatkan volume signifikan pasca pengumuman kabinet Indonesia Maju pada tanggal 23 Oktober 2019. Berikut adalah statistik deskriptif terkait informasi perdagangan saham pada periode terjadinya peristiwa. 
Tabel 9. Rata-rata Volume Perdagangan Saham

\begin{tabular}{cc}
$\mathbf{t}$ & $\begin{array}{c}\text { Volume Perdagangan } \\
\text { Saham }\end{array}$ \\
-5 & $0,15 \%$ \\
-4 & $0,14 \%$ \\
-3 & $0,20 \%$ \\
-2 & $0,15 \%$ \\
-1 & $0,12 \%$ \\
0 & $0,16 \%$ \\
1 & $0,21 \%$ \\
2 & $0,16 \%$ \\
3 & $0,12 \%$ \\
4 & $0,20 \%$ \\
5 & $0,14 \%$ \\
\hline
\end{tabular}

Tabel 9 menunjukkan rata-rata volume perdagangan saham yang terjadi pada periode jendela. Nilai tertinggi terjadi pada $\mathrm{t}+1$ sebesar $0,21 \%$ saham diperdagangkan pada tanggal tersebut. Nilai terendah terjadi pada hari t-1 dan t+3 sebesar $0,12 \%$. Secara keseluruhan jumlah saham yang diperdagangkan relatif kecil karena tidak mencapai $1 \%$ dari total saham yang beredar pada hari tersebut. Untuk menguji hipotesis maka diperlukan uji statistik terhadap variabel volume perdagangan saham. Uji hipotesis yang digunakan adalah uji beda (uji paired sample $t$ test) untuk setiap hari dalam periode peristiwa. Hasil pengujian uji beda dapat dilihat pada tabel dibawah ini.

Tabel 10. Hasil Uji Paired Sample untuk Volume Perdagangan Saham

\begin{tabular}{|c|c|c|c|c|c|c|}
\hline & & Mean & $\begin{array}{c}\text { Std. } \\
\text { Deviatio } \\
\text { n }\end{array}$ & $\begin{array}{l}\text { Std. } \\
\text { Error } \\
\text { Mean }\end{array}$ & $\mathbf{t}$ & $\begin{array}{l}\text { Sig. (2- } \\
\text { tailed) }\end{array}$ \\
\hline Pair & $\begin{array}{l}\text { sebelum } \\
\text { sesudah }\end{array}$ & - & ,00060 & ,00027 &,- 488 & ,651 \\
\hline
\end{tabular}

Hasil pengujian menunjukkan bahwa nilai signifikansi masih di atas 0,05 yang mana mengindikasikan bahwa hipotesis ditolak. Kesimpulan yang diambil adalah tidak terdapat perbedaan volume perdagangan saham sebelum 
dan sesudah pengumuman kabinet Indonesia Maju pada tanggal 23 Oktober 2019 silam. Hasil ini sejalan dengan pengujian abnormal return yang menunjukkan tidak ada perbedaan

\section{KESIMPULAN}

Berdasarkan hasil pengujian dan pembahasan diperoleh simpulan bahwa peristiwa pengumuman kabinet Indonesia Maju pada tanggal 23 Oktober 2019 tidak menimbulkan reaksi investor secara signifikan. Pengujian abnormal return melibatkan variabel average abnormal return dan cumulative average abnormal return. Untuk seluruh hari yang diuji pada sampel penelitian yaitu 5 hari sebelum dan 5 hari sesudah peristiwa tidak menunjukkan adanya reaksi signifikan yang menyebabkan adanya abnormal return yang didapat oleh investor. Hasil uji paired sample juga menunjukkan tidak terdapat perbedaan rata-rata abnormal return dan volume perdagangan saham yang signifikan antar sebelum dan sesudah peristiwa. Penyebabnya dapat berupa informasi pengumuman kabinet belum menunjukkan potensi signifikan bagi ekonomi dan pasar modal Indonesia. antara rata-rata abnormal return sebelum dan sesudah peristiwa pengumuman kabinet oleh presiden Joko Widodo.

Beberapa nama baru yang ditunjuk oleh Presiden belum dapat menunjukkan kinerja sehingga periode jendela dalam penelitian ini tidak dapat menangkap nilai informasi yang material bagi pengambilan keputusan investor. Penelitian ini memiliki beberapa keterbatarasan antara lain jumlah sampel penelitian yang masih sedikit, penggunaan market model yang masih sederhana dalam menghitung return ekspektasian, dan periode jendela yang masih pendek. Untuk itu, kedepannya penelitian berikutnya dapat mempertimbangkan aspek-aspek tersebut dalam mereplikasi penelitian serupa. Peneliti selanjutnya hendaknya menggunakan sampel yang lebih umum bukan hanya terkonsentrasi pada indeks sektoral. Selain itu, penentuan tanggal peristiwa harus jelas dan memastikan tidak ada informasi yang bocor sebelum peristiwa terjadi karena akan menyebabkan penghitungan return abnormal menjadi tidak andal. 


\section{DAFTAR PUSTAKA}

Alrhafynza, F. B., \& Siswanto, E. (2018). Reaksi Pasar Modal Indonesia Terhadap Peristiwa Politik Nasional. 11.

Arde, M. H. D., \& Kesuma, K. W. (2017). Studi Peristiwa Tragedi Sarinah Terhadap Pasar Modal Indonesia. 6(6), 31.

Ateris Bilada. (2010). Dampak extreme events terhadap return indeks harga saham gabungan (ihsg) dan indeks sektoral. 2.

Dewi, M. I. A., Amin, M., \& Mawardi, M. C. (2018). Reaksi Investor Dalam Pasar Modal Terhadap Peristiwa Aksi Bela Islam 4 November 2016 Di Jakarta. 07(07), 13.

Foresti, P., \& Napolitano, O. (2016). On the Stock Markets' Reactions to Taxation and Public Expenditure. 26.

Hartono, Jogiyanto. (2016). Teori Portofolio dan Analisis Investasi, Ed. 7, Yogyakarta: BPFE UGM.

Hartono, Jogiyanto. (2015). "Studi Peristiwa (Menguji Reaksi Pasar Modal Akibat Suatu Peristiwa)". Yogyakarta: BPFE UGM.

Hatmanti, A., \& Sudibyo, B. (2017). Pengaruh Pelantikan Kabinet Kerja Hasil Reshuffle Jilid II Terhadap Harga Saham LQ-45. Jurnal Economia, 13(1), 1. https://doi.org/10.21831/econom ia.v13i1.11797

Janke, F., Packová, M., \& Prídavok, M. (2015). Stock market reaction to ict implementation: Model based on comparison of developed and transition economies. $\mathrm{E}+\mathrm{M}$ Ekonomie a Management, 18(3), https://doi.org/10.15240/tul/001/ 2015-3-009

Karim, M. A., Rathinasamy, R., \&

Zaidi, S. K. (2018). Market Reaction To Split Announcements: Rational Response Or Behavioural Bias? 22(2), 15.

Liwe, C. T. S., Tommy, P., \& Maramis, J. B. (2018). Reaksi Investor Dalam Pasar Modal Atas Peristiwa Menguatnya Kurs Dolar Amerika Serikat Terhadap Nilai Tukar Rupiah Pada 26 Agustus 2015 (Study pada perusahaan manufaktur sub sektor food and beverage yang listed di BEI). 10.

Maharani, A. N. (2018). Reaksi Pasar Modal Terhadap Pengumuman Paket Kebijakan Ekonomi Jilid 1, 5, 7, 11 DAN 13. 10(2), 9.

Melati, D. A. (2016). Analisis Reaksi Pasar Modal Atas Peristiwa Pemilihan Presiden 9 Juli 2014 (Event Study Pada Indeks Saham LQ-45). 11.

Pierz, A. M. (2016). Stock Market Reaction to Corporate Political Activity. 56.

Rofiki, D. (2017). Reaksi Pasar Modal Indonesia Akibat Peristiwa Pemilihan Gubernur Dki Jakarta Putaran II 2017 (Event Study Pada Saham Perusahaan Yang Terdaftar Di Indeks Lq45 Periode. 9. 
Salengke, M. R. D. S. S. D. (2018).

Analysis Of Comparison The Composite Stock Price Index Before And After Increasing The Investment Grade At Indonesia Stock Exchange. Tasharruf: Journal Economics and Business of Islam, 3(1). https://doi.org/10.30984/tjebi.v3 i1.655

Satria, G. A., Artini, L. G. S., \& Rahyuda, H. (2017). Reaksi Pasar Terhadap China's Black Monday di Bursa Efek Indonesia. E-Jurnal Ekonomi dan Bisnis Universitas Udayana,2635.https://doi.org/10 .24843/EEB.2017.v06.i07.p02

Siwantara, K. R., Sinarwati, N. K., \& Yuniarta, G. A. (2015). Reaksi Investor Dalam Pasar Modal Terhadap Peristiwa Kenaikan Bahan Bakar Minyak. 3(1), 10.

Škrinjarić, T. (2019). Stock Market

Reactions to Brexit: Case of Selected CEE and SEE Stock Markets. International Journal of Financial Studies, 7(1), 7. https://doi.org/10.3390/ijfs7010 007

Wahyuni, S. (n.d.). Reaksi Investor terhadap Pengumuman laba: Pengujian atas Pengungkapan Informasi Management Guidance. 28.

Wibowo, A. (2017). Reaksi Investor Pasar Modal Indonesia Terhadap Paket Kebijakan Ekonomi Tahap I Jokowi - JK ( Studi pada Saham LQ 45 Periode Agustus 2015 - Pebruari 2016 ). 